\title{
Productivity and Participatory Evaluation of Forage Legumes and Grasses in Pour Soils of Ngweshe Kingdom, DRC
}

\author{
M. M. D. Katunga ${ }^{1,2}$, P. B. Mushagalusa ${ }^{1}$, B. Kambale ${ }^{3}$ \\ ${ }^{1}$ INERA Mulungu, Bukavu, DRC \\ ${ }^{2}$ Université du cinquantenaire de Lwiro, Bukavu, DRC \\ ${ }^{3}$ Université Évangélique en Afrique (UEA), Bukavu, DRC \\ Email: stylonya@gmail.com, pyamemushagalusa@gmail.com, \\ stylonya@gmail.com, blaisekambale@gmail.com
}

How to cite this paper: Katunga, M.M.D., Mushagalusa, P.B. and Kambale, B. (2020) Productivity and Participatory Evaluation of Forage Legumes and Grasses in Pour Soils of Ngweshe Kingdom, DRC. Open Access Library Journal, 7: e6611.

https://doi.org/10.4236/oalib.1106611

Received: July 14, 2020

Accepted: September 14, 2020

Published: September 17, 2020

Copyright $\odot 2020$ by author(s) and Open Access Library Inc.

This work is licensed under the Creative Commons Attribution International License (CC BY 4.0).

http://creativecommons.org/licenses/by/4.0/

\section{(c) (i) Open Access}

\begin{abstract}
Livestock production decreases in DRC during the three last decades. Malnutrition becomes a big challenge especially in animal proteins supply. To improve animal production by the best feeding in rural environment of Sud-Kivu, International Institute of Tropical Agriculture (IITA) selected four legume forages: Desmodium uncinatum, Canavalia brasiliensis CIAT 17009, Lablab purpureus 21603 and Lablab purpureus 22759 and grasses Tripsacum andersonii, Pennisetum purpureum CV French Cameroon and local Pennisetum purpureum to test their agronomic performances in Ngweshe kingdom. Trials were in completely randomized blocs and duplicated three times up 2014 to 2015 . There were three sites for the legumes and five for the grasses. Results showed that the forage legumes Canavalia brasiliensis CIAT 17009 and Desmodium uncinatum CV ILRI 6765 had good agronomic performances. Lablab purpureus (CIAT 21603 and CAT 22579) didn't present good adaptability. The best forage grasses were successively Tripsacum andersonii and Pennisetum purpureum CV French Cameroon. These best forage legumes and grasses were also well appreciated by the farmers.
\end{abstract}

\section{Subject Areas \\ Agricultural Science}

\section{Keywords}

Forage Legumes and Grasses, Agronomic Performances, Participatory

Evaluation, DRC 


\section{Introduction}

Sud-Kivu province faces malnutrition with $70 \%$ of his population due to lack of food especially the animal proteins such as milk, meat, eggs. Prices of these commodities are not accessible to the population [1] [2]. The food insecurity comes from long time in this region and appears sometimes with various intensities [3] [4]. Agriculture is mainly practiced in the traditional system and cannot respond to the demand of population explosion with $2.8 \%$ rate of growth [5]. Natural pasture spaces are progressively replaced by the fields with crops. Livestock production is low due to low extension services, lack of animal feeding mostly during the dry season, lack of veterinaries inputs, insecurity, etc. In this way, the promotion of forage crops presents many advantages to the farmers. It can contribute to supplying animal feeding in quantity and quality mainly during the two seasons of the year. Livestock and crops still are producing under the traditional system. Animal feed is principally supplied from the grasslands.

Various studies were carried out in the region to adapt the forage species [6]-[11], etc. Recently the adaptation of some forage legumes from latino-america by the "Centre International d'Agriculture Tropicle" (CIAT) showed that Stylosanthes guianensis 11995, Stylosanthes guianensis Cook, Centrosema molle, Canavalia brasiliensis, Desmodium uncinatum, Desmodium intortum, Macroptilium atropurpureum and Lablab purpureus 21603 were well adapted according to their yield herbage in the middle and high altitudes of Sud-Kivu and their performances confirmed by the farmer's choice [12]. IITA in the Humid tropics program, mainly in his Cluster 4 project implemented this trial in Ngweshe [13]. The choice of these forages was a continuation of the forage legumes adaptation on which we added some best grasses for cut and carry forage system. The main objective of this study is to evaluate the performance of some forage legumes and grasses and their appreciation by farmers in the Ngweshe kingdom, Sud-Kivu province.

\section{Materials and Methods}

\section{Location}

Mushinga and Mulamba "groupements" are located in Ngweshe kingdom, Walungu territory, Sud-Kivu. Walungu territory is at $2^{\circ} 35^{\prime}$ South latitude and $28^{\circ} 40^{\prime}$ longitude East with an altitude up 1000 to $2500 \mathrm{~m}$ in Sud-Kivu, DRC. Figure 1 shows the map of Ngweshe kingdom.

\section{Sites}

Legume trials were tested in Mushinga "groupement" in three sites Cirhongo, Karhambi and Mubumbano villages and for grasses in Mushinga "groupement" with five sites Cirhongo, Cizi, Karhambi, Mubumbano and in Mulamba "groupement" at Mulamba road site. Table 1 shows the soil characteristics of these sites.

\section{Trial designs}

-Forage legumes

Four legume forages from CIAT were tested: Canavalia brasiliensis CIAT 


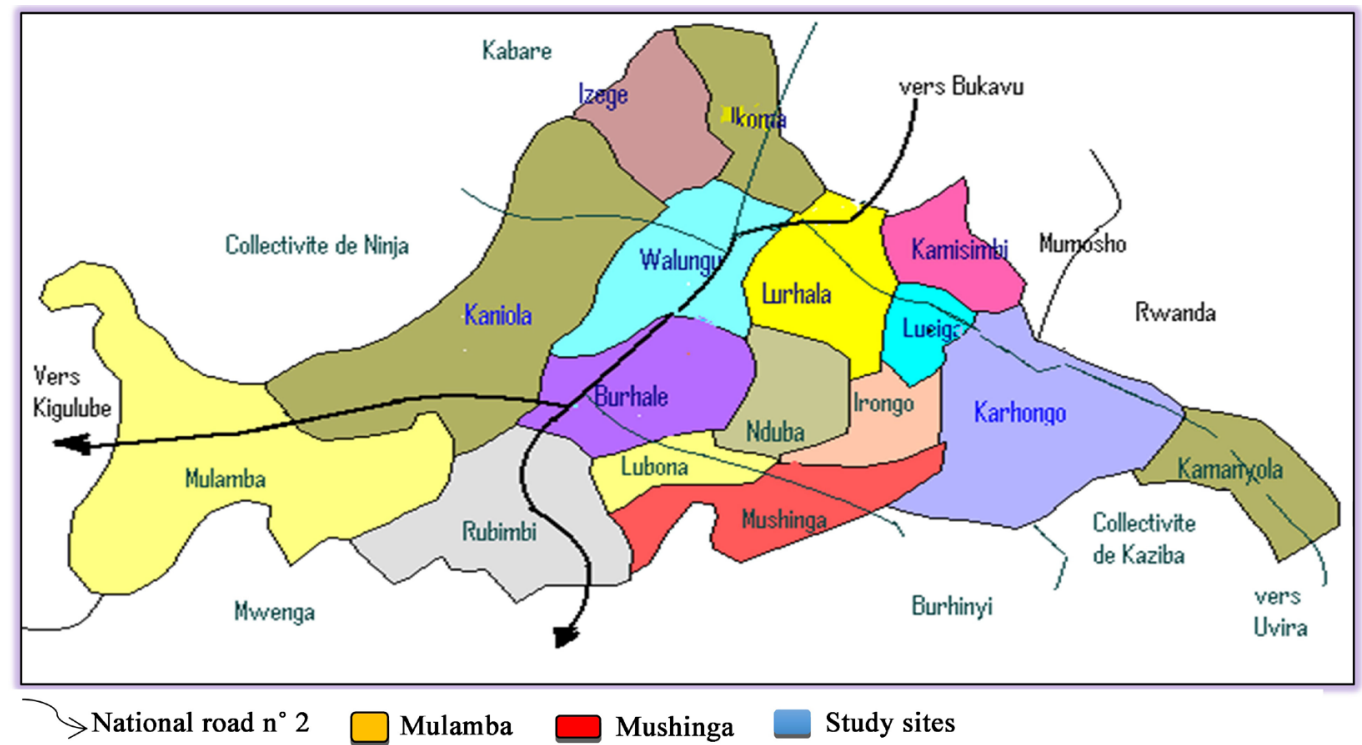

Figure 1. Map of Ngweshe kingdom (Source: Geography department/ISP-Bukavu DRC).

Table 1. Soils characteristics of the sites.

\begin{tabular}{|c|c|c|c|c|c|c|c|}
\hline Sites & $\mathrm{pH}$ in water & $\begin{array}{c}\text { Exchangeable } \\
\text { calcium (me/100g } \\
\text { soil) }\end{array}$ & $\begin{array}{c}\text { Exchangeable } \\
\text { magnesium (me/100g } \\
\text { soil) }\end{array}$ & $\begin{array}{c}\text { Exchangeable } \\
\text { potassium (me/100g } \\
\text { soil) }\end{array}$ & $\begin{array}{c}\text { Extractable } \\
\text { phosphorus (mg } \\
\mathrm{P} / \mathrm{kg} \text { ) }\end{array}$ & $\begin{array}{l}\text { Total soil } \\
\text { organic } \\
\text { carbon }(\%)\end{array}$ & $\begin{array}{c}\text { Total Soil } \\
\text { nitrogen (\%) }\end{array}$ \\
\hline Cizi & 4.71 & 0.59 & 0.59 & 0.07 & 4.1 & 1.29 & 0.16 \\
\hline Cirhongo & 4.50 & 0.98 & 0.30 & 0.03 & 5.3 & 1.45 & 0.19 \\
\hline Karambi & 4.37 & 0.69 & 0.20 & 0.02 & 2.8 & 2.82 & 0.19 \\
\hline Mubumbano & 4.63 & 0.79 & 0.49 & 0.02 & 5.0 & 3.09 & 0.30 \\
\hline Mulamba route & 5.01 & 1.28 & 0.30 & 0.02 & 5.0 & 3.00 & 0.43 \\
\hline
\end{tabular}

[14].

17009, Desmodium uncinatum ILRI 6765 CV Silver leaf, accessions of Lablab purpureus (CIAT 21603 and CIAT 22759). Each plot measured $3 \mathrm{~m} \times 1.5 \mathrm{~m}$ and $1 \mathrm{~m}$ of pathway between the plots. Sowing spacing within the plot was $0.25 \mathrm{~m} \times$ $0.5 \mathrm{~m}$. Trials were implemented from October 2014. The regularization cutting was done after $50 \%$ of flowered average in the plots in March, 2015. After the regularization cutting, harvests were undertaken after eight weeks at two harvesting times, one in May, 2015 during the wet season and another in July 2015 during the dry season.

-Forage grasses

Pennissetum purpureum CV French Cameroon (P.p.C or French Cameroon), local Pennissetum purpureum Schumach. (P.p.local or local Napier grass) and Tripsacum andersonii J.R. Gray were tested.

Plantation held on September, $28^{\text {th }}$ to $30^{\text {th }} 2014$. They were planted at $1 \mathrm{~m} \mathrm{x} 1$ $\mathrm{m}$ and each plot measured $4 \mathrm{~m} \times 3 \mathrm{~m}$, pathway between plots measured $2 \mathrm{~m}$. Regularization cutting was done after 6 months of forages establishment in March, $6^{\text {th }} 2015$, harvest cuttings times in each eight weeks after the regulation 
cutting; one in wet season in May 2015 and another one in dry season in July 2015.

Trials were established for both legumes and grasses in randomized complete design with three replications. Following parameters were observed: germination rate, soil cover, height, yield production in dry matter (DM) and farmer's participatory evaluation. Only before sowing and plantation of legumes and grasses, three hands of cattle manure were put in the hollow. Data were analyzed by Statisticx 8.0 and Statview softwares. Figure 2 and Figure 3 were made by Microsoft Excel.

\section{Results}

\section{Germination}

\section{Soil cover rates}

As shown in Table 2, there was a significant difference $(\mathrm{P}<0.05)$ between the

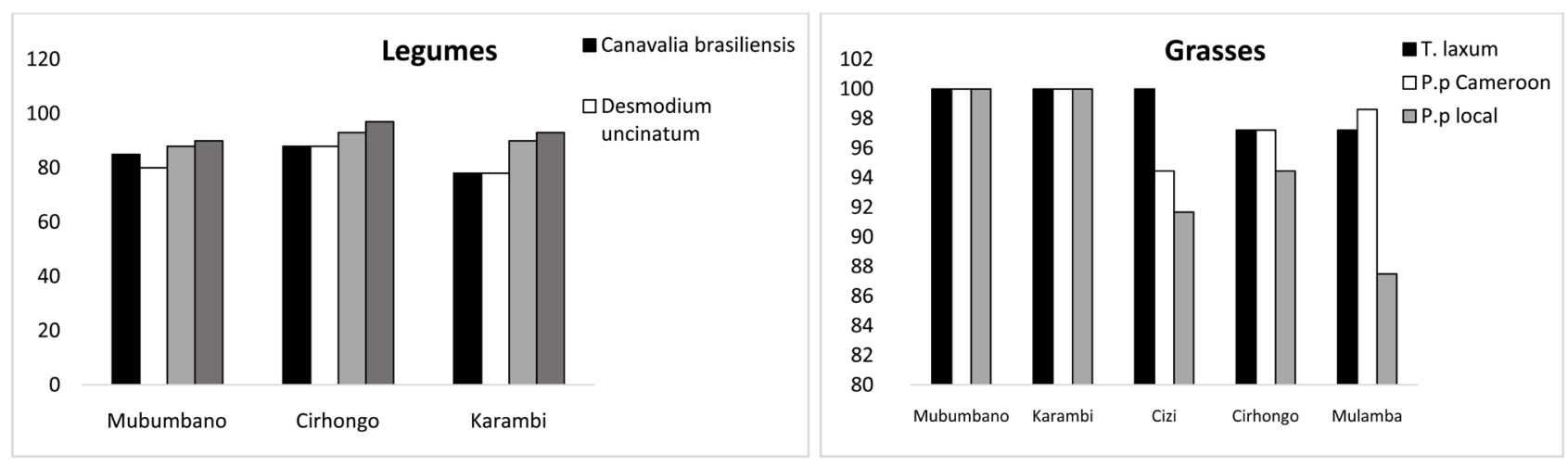

Figure 2. Germination rates. On legumes, means rate of germination of legumes were $82.2 \%$ for C. brasiliensis, $80.6 \%$ D. uncinatum, $90.6 \%$ L. purpureus $21603,93.3 \%$. L. purpureus 22579 . The rates mean of germination in the sites were in Cirhongo $89.1 \%$, Karambi $\mathbf{8 5 . 0 \%}$ and Mubumbano $85.8 \%$. The means rate forage grasses of germination were $97.5 \%$ French Cameroon, $94.5 \%$ local Napier grass and $98.8 \%$ T. andersonii. According to the mean rates of germination in the sites, Mubumbano and Karambi recorded maximum 100\%, Cirhongo $96.1 \%$, Cizi 95.2\% and Mulamba road 94.2\%.
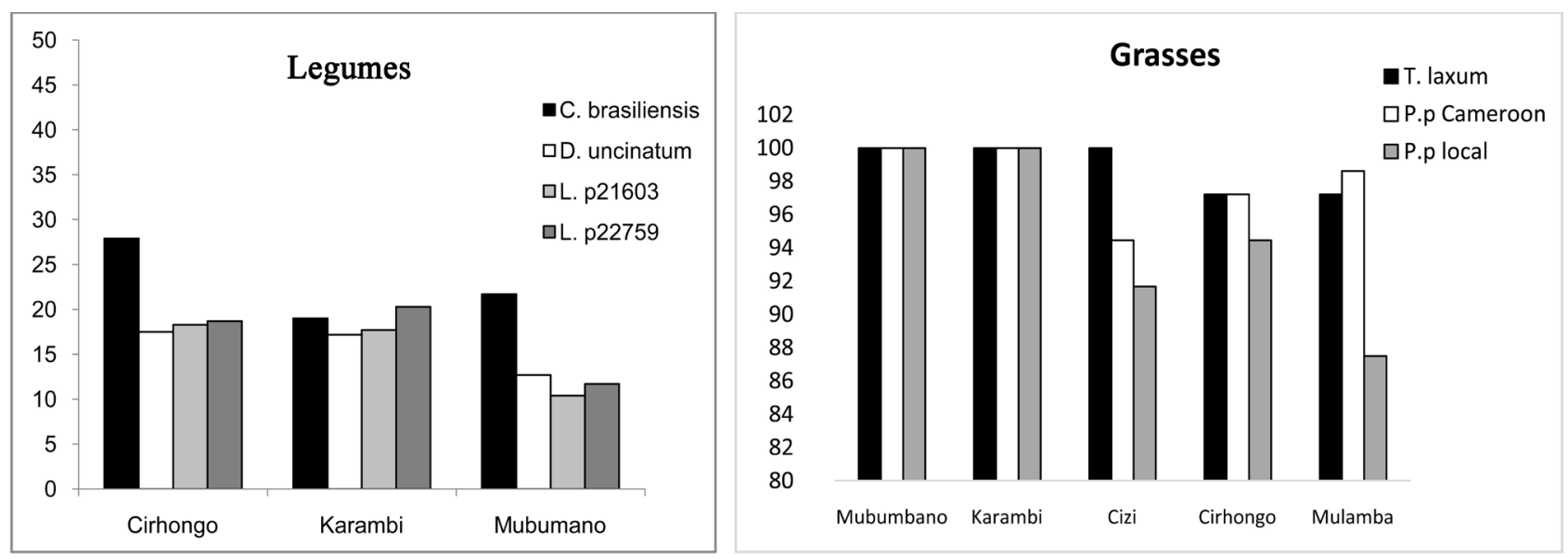

Figure 3. Farmer's participatory evaluation of forage legumes and grasses. On farmer's participatory evaluation, among the legumes, D. uncinatum CV ILRI 6765 was the most appreciated. It was followed by $C$. brasiliensis CIAT 17009. On grasses, $T$. andersonii and French Cameroon were appreciated. 
means soil cover rates of forage legumes species and accessions from Chi-square test. C. brasiliensis had the best soil cover followed by $D$. uncinatum. There was any difference $(\mathrm{P}>0.05)$ between the mean's soil cover rates compare to the sites. In general the soil cover is not interesting in the entire site, mainly for the two L. purpureus.

As shown in Table 3, the Chi-square test showed that there was no significant difference $(\mathrm{P}>0.05)$ between the means of soil cover of forage grasses species and sites. The high of forage grasses species cover mean of was $T$. andersonii while according to the site, Mubumbano recovered more.

\section{Height}

As shown in Table 4, the comparison of means heights showed that there was no significant difference $(\mathrm{P}>0.05)$ between the means of forage species and accessions. $C$. brasiliensis was the highest while Cirhongo site had the tallest legumes.

Table 2. Legumes soil cover (\%).

\begin{tabular}{ccccc}
\hline Legume species & \multicolumn{3}{c}{ Sites } & $\begin{array}{c}\text { Grand mean } \\
\text { species }\left(^{*}\right)\end{array}$ \\
\cline { 2 - 4 } & Cirhongo & Karambi & Mubumbano & $71.4 \pm 29.0$ \\
C. brasiliensis 17009 & 74.2 & 65.8 & 74.2 & $70.3 \pm 24.7$ \\
D. uncinatum & 76.7 & 65.8 & 68.3 & $25.8 \pm 17.8$ \\
L. purpureus 21603 & 28.3 & 28.3 & 20.8 & $17.8 \pm 13.9$ \\
L. purpureus 22759 & 18.3 & 16.7 & 18.3 & 46.3 \\
Grant mean sites & $49.4 \pm 30.3$ & $44.2 \pm 25.3$ & $45.4 \pm 18.0$ & \\
\hline
\end{tabular}

Table 3. Grasses soil cover (\%).

\begin{tabular}{cccccccc}
\hline & \multicolumn{9}{c}{ Sites } & & Grand mean \\
\cline { 2 - 7 } Grasses species & Cirhongo & Cizi & Karambi & Mubumbano & $\begin{array}{c}\text { Mulamba } \\
\text { route }\end{array}$ & species \\
P.p. $C$ & 55 & 60 & 53 & 62 & 45 & $67.0 \pm 4.4$ \\
P.p.local & 70 & 65 & 60 & 70 & 70 & $55.0 \pm 6.7$ \\
T. andersonii & 80 & 70 & 65 & 75 & 70 & $72.0 \pm 5.9$ \\
Grant mean sites & $68.3 \pm 12.6$ & $65.0 \pm 5.0$ & $59.3 \pm 6.0$ & $69.0 \pm 6.5$ & $61.7 \pm 14.4$ & 64.7
\end{tabular}

Table 4. Legumes forage height $(\mathrm{cm})$.

\begin{tabular}{ccccc}
\hline Legume species & \multicolumn{3}{c}{ Sites } & \multirow{2}{*}{$\begin{array}{c}\text { Grand mean } \\
\text { species }(*)\end{array}$} \\
\cline { 2 - 4 } & Cirhongo & Karambi & Mubumbano & $22.9 \pm 6.7$ \\
\hline C. brasiliensis 17009 & $27.9 \pm 5.4$ & $19.0 \pm 7.5$ & $21.7 \pm 4.2$ & $15.8 \pm 5.5$ \\
D. uncinatum & $17.5 \pm 5.5$ & $17.2 \pm 7.3$ & $12.7 \pm 2.1$ & $15.5 \pm 7.5$ \\
L. purpureus 21603 & $18.3 \pm 7.0$ & $17.7 \pm 8.0$ & $10.4 \pm 5.7$ & $16.9 \pm 10.1$ \\
L. purpureus 22759 & $18.7 \pm 8.1$ & $20.3 \pm 14.2$ & $11.7 \pm 5.6$ & 17.8 \\
\hline Grant mean sites & $20.6 \pm 5.0$ & $18.6 \pm 1.4$ & $14.1 \pm 5.1$ & \\
\hline
\end{tabular}


As shown in Table 5, there was a high difference $(\mathrm{P}<0.001)$ between the means comparison of the height forage grasses species and sites. French Cameroon was the tallest followed by local Napier grass. Cirhongo site had the tallest grasses.

\section{Forages yield}

As shown in Table 6, the comparison yield herbage showed a high significant different $(\mathrm{P}<0.001)$ between means legumes forage species and accessions and sites. $C$. brasiliensis and $D$. uncinatum performed well than the two accessions of L. purpureus. Cirhongo site produced more biomass.

As shown in Table 7 , there was a high difference $(\mathrm{P}<0.001)$ between the means comparison of the yield forage grasses by species and sites. French Cameroon produced more biomass followed by $T$. andersonii and the local Napier grass was the last one. Cirhongo site produced more biomass followed by Cizi site.

Forages participatory evaluation

Farmer's choice was conducted principally by the following criteria: yield

Table 5. Grasses forage height $(\mathrm{cm})$.

\begin{tabular}{ccccccc}
\hline & \multicolumn{9}{c}{ Sites } & & Grand mean \\
\cline { 2 - 7 } Grass species & Cirhongo & Cizi & Karambi & Mubumbano $\begin{array}{c}\text { Mulamba species (***) } \\
\text { road }\end{array}$ \\
\cline { 2 - 7 } P.p.C & $151 \pm 26$ & $114 \pm 18$ & $108 \pm 43$ & $139 \pm 23$ & $111 \pm 14$ & $124.6 \pm 19.2$ \\
P.p.local & $136 \pm 45$ & $136 \pm 28$ & $88 \pm 24$ & $112 \pm 31$ & $89 \pm 38$ & $112.2 \pm 23.7$ \\
T. andersonii & $129 \pm 55$ & $92 \pm 14$ & $82 \pm 44$ & $111 \pm 15$ & $89 \pm 18$ & $100.6 \pm 19.2$ \\
Grant mean sites $\left.{ }^{* * *}\right)$ & $138.7 \pm 42$ & $114 \pm 27$ & $92.7 \pm 37 \mathrm{~d}$ & $120.7 \pm 26$ & $96.3 \pm 26$ & 112.5 \\
\hline
\end{tabular}

Table 6. Legumes herbage yield (DM kg/ha).

\begin{tabular}{ccccc}
\hline \multirow{2}{*}{ Legume species } & \multicolumn{3}{c}{ Sites } & $\begin{array}{c}\text { Grand mean } \\
\text { species (***) }\end{array}$ \\
\cline { 2 - 5 } & Cirhongo & Karambi & Mubumbano & $788.2 \pm 519.6$ \\
\hline C. brasiliensis 17009 & $1302.3 \pm 447.2$ & $340.7 \pm 192.6$ & $721.6 \pm 343.9$ & $734.9 \pm 512.5$ \\
D. uncinatum & $1047.3 \pm 534.7$ & $291.6 \pm 114.6$ & $865.7 \pm 469.5$ & $111.6 \pm 168.0$ \\
L. purpureus 21603 & $246.4 \pm 248.3$ & $40.0 \pm 31.1$ & $48.3 \pm 25.5$ & $125.4 \pm 165.7$ \\
L. purpureus 22759 & $241.1 \pm 259.6$ & $65.0 \pm 27.4$ & $70.0 \pm 31.9$ & 440.0 \\
Grand mean sites $(* * *)$ & $709.3 \pm 547.5$ & $184.3 \pm 153.9$ & $426.4 \pm 48.3$ &
\end{tabular}

Table 7. Grasses herbage yield (DM kg/ha).

\begin{tabular}{|c|c|c|c|c|c|c|}
\hline \multirow{2}{*}{ Grasse species } & \multicolumn{5}{|c|}{ Sites } & \multirow{2}{*}{$\begin{array}{l}\text { Grand mean } \\
\text { species }(* * *)\end{array}$} \\
\hline & Cirhongo & Cizi & Karambi & Mubumbano & Mulamba route & \\
\hline P.p.local & $2902.8 \pm 2158.3$ & $1942.2 \pm 1054.3$ & $367.8 \pm 214$ & $1991.3 \pm 568.6$ & $296.17 \pm 73.5$ & $1500.1 \pm 1456.7$ \\
\hline T. andersonii & $2539 \pm 1187.5$ & $3224 \pm 1311.8$ & $1860.8 \pm 1686.3$ & $2989.7 \pm 372.2$ & $1485.2 \pm 551.8$ & $2419.7 \pm 1247.3$ \\
\hline Grant mean sites ${ }^{\star * *}$ & $3339.4 \pm 429.6$ & $3180.2 \pm 974.0$ & $1590.1 \pm 206.9$ & $3039.5 \pm 206.9$ & $1511.9 \pm 225$ & 2532.4 \\
\hline
\end{tabular}


production, resistance against diseases and pests, soil cover by the forage etc. The figure below shows the rates of farmer's choice.

\section{Discussion and Conclusion}

\section{Germination}

The legumes rate of germination was observed between 69.0\% (Desmodium uncinatum CV ILRI 6765) and 98.0\% (Lablab purpureus CIAT 22759). These results are like those observed by [15]. On grasses, the range of germination was almost equal between $94.5 \%$ to $98.8 \%$ for the three grasses tested.

\section{Height}

On forage legumes, [12] observed that the tallest legumes were L. purpureus 21603 with $38.8 \mathrm{~cm}$, L. purpureus 22795 with $38.0 \mathrm{~cm}$ and C. brasiliensis 33.8 $\mathrm{cm}$. Height of these forage legumes was low than those observed previously in Sud-Kivu. The reason to this situation is probably due to the soil fertility gra-

dient. C. brasiliensis CIAT 17009 was the tallest $(22.8 \mathrm{~cm})$. According to the grasses, the two $P$. purpureum were taller than $T$. andersonii. Zewdu et al. observed that plant height at cutting increased from $0.5 \mathrm{~m}$ to $1.5 \mathrm{~m}$, in vitro digestibility of dry matter declined from $71.74 \%$ to $61.03 \%(\mathrm{P}<0.05)[16]$.

\section{Soil cover}

The soil cover of legumes $D$. uncinatum CV ILRI 6765 with $71 \%$ was the best and was followed by C. brasiliensis CIAT 17009 with 70\%. These results were well similar to those observed by [12], except the low rate of the two accessions of $L$. purpureus perhaps due to the degeneration of the seeds. On grasses, $T$. andersonii from his large leaves was the best grass to cover the soil than French Cameroon even if this last had also good leave coverage than the local $P$. purpureum, as observed also [17].

\section{Yield}

The herbage yield of $C$. brasiliensis CIAT 17009 and D. uncinatum ILRI 6765 was higher than the two accessions of Lablab purpureus. This is due to their flexibility of large diversity on soil fertility [18]. We can also observe that in Nyangezi and Tubimbi on acidic soils. C. brasiliensis produced without inputs $1132.1 \mathrm{~kg} / \mathrm{ha}$. L. purpureus 21603 and L. purpureus 22759 had respectively produced $451 \mathrm{~kg} / \mathrm{ha}$ and $741.5 \mathrm{~kg} / \mathrm{ha}$ [19]. These yield herbages are more important compared to those observed in Mushinga. French Cameroon produced successively with two cuttings in wet and dry seasons $3.7 \mathrm{DM} \mathrm{t} / \mathrm{ha}$ and local $P$. purpureum 1.5 DM t/ha. With fertilization, $P$. purpureum can produce 10 - 30 t/ha of DM biomass and in unfertile soils $2-10$ t/ha [20]. In Rwanda $P$. purpureum produced $17 \mathrm{DM}$ t/ha harvesting interval was each three months during one year [21]. T. andersonii produced during two cuttings $2.4 \mathrm{DM} \mathrm{t} / \mathrm{ha}$ while [20] reported in good conditions an annual DM yield of $18-22 \mathrm{t} / \mathrm{ha}$. In general, forage yield in Ngweshe was low due probably to few cuttings number and low soils quality (see Table 1). All the rate of minerals are very low [14], even if Mulamba road had some good rates than the others sites but his ration 
C/N 7.0 was very low.

\section{Participatory evaluation}

On legume forages, $C$. brasiliensis and $D$. uncinatum were the best chosen by the farmers. Among grasses evaluated, the first choice of farmers was $T$. andersonii followed by French Cameroon. Farmer's choice showed that their decision was practically similar to the agronomic trial outputs [12].

\section{Acknowledgements}

Funding of this research came from the International Institute of Tropical Agriculture (IITA) in the Humid-Tropics program.

\section{Conflicts of Interest}

The authors declare no conflicts of interest regarding the publication of this paper.

\section{References}

[1] SNS (2012) National Statistics Service. Annual Report 2012. RDC, Sud-Kivu.

[2] FAO (2010) Livestock and Animal Industry State of Mater in Central Africa Countries. Libreville Gabon, 93 p.

[3] Katunga, M.M. (2004) Agropastoral Systems of Bushi and Buhavu East RDC Face to Malnutrition Challenge. CERPRU ISDR Bukavu RDC, 89 p.

[4] Katunga, M.M.D. and Muhigwa, J.B. (2014) Herbaceous Forage Legumes Adaptation in Acidic Soils in South-Kivu. DRC Journal of Applied Biotechnology, 3, 24 p. https://doi.org/10.5296/jab.v3i1.6548

[5] UNPD (2009) Unite Nations Programme of Development. Unity against Poverty. Agriculture Production Statistics, Horticulture and Animal in RDC.

[6] Blouard, R. and Behaege, T. (1961) Establishment of Pastures and Equatorial Forest Exploitation B.I INEAC X (2).

[7] Blouard, R. and Thauriaux, L. (1962) Stylosanthes gracilis His Composition and Use in Congo B.I INEAC IX (46).

[8] Compère, R. (1960) Introduction in Kivu of Tripsacum andersonii Nash Forage Welt Animal Crops for Dairy Livestock Agricultural Bulletin of Congo. LI (5).

[9] Compère, R. (1960) Productivity and Chemical Forages Values of Some Learnt Pastures at Mulume (Kivu) Station Agricultural Bulletin of Belgian Congo LII (1).

[10] Compère, R. (1961) Behaviour of Mixed Forages of Trifolium repens-Grasses in High Altitude Regions in Kivu. INEAC Technique Series 65.

[11] Katunga, M.M.D., Muhigwa, J.B.B., Kashala, K.J.C., Ipungu, L., Nyongombe, N., Maass, B.L. and Peters, M. (2014) Testing Agro-Ecological Adaptation of Improved Herbaceous Forage Legumes in South-Kivu. DRC American Journal of Plant Sciences, 5, 1384-1393. http://www.scirp.org/journal/ajps https://doi.org/10.4236/ajps.2014.59153

[12] Katunga, M.M.D. (2013) Evaluation of Forage Legumes in Livestock System European Universities Editions (08-07-2014). http://www.editions-ue.com

[13] Lamers, D., Mapatano, S., Katunga, M.M.D., Lunzihirwa, J., Zozo, R., Okafor, C., Sartas, M. and Schut, M. (2015) Building Multi-Stakeholder Processes in Agricul- 
tural Research for Development in DR Congo. Case Study Developed under the CGIAR Research Program on Integrated Systems for the Humid Tropics (Humid Tropics) by Wageningen University (WUR) and the International Institute of Tropical Agriculture (IITA).

https://www.dropbox.com/sh/cx69ysna6acm56o/AADekPvnQTjsNljR10BJEJ8Ia?dl $\underline{\underline{0}}$

[14] IITA (2014) Report of Mushinga Activities in Humid Tropics Program. Cluster four Obasanjo Campus Kalabo Bukavu DRC.

[15] Skerman, P.J. (1982) Forages Legumes. FAO Collection, Vegetal Production and Protection No. 2. Rome. $666 \mathrm{p}$.

[16] Zewdu, T., Baars, R.M.T. and Yami, A. (2002) Effect of Plant Height at Cutting. Source and Level of Fertiliser on Yield and Nutritional Quality of Napier Grass (Pennisetum purpureum (L.) Schumach.). Africa Journal of Range Forages \& Sciences, 19, 123-128. https://doi.org/10.2989/10220110209485783

[17] Paul, B.K., et al. (2015) Towards an Assessment of On-Farm Niches for Improved Forages in Sud-Kivu. DRC Journal of Agriculture and Rural Development in the Tropics and Subtropics, 117, 243-254.

[18] Husson, O., Charpentier, H., Razanamparany, C., Moussa, N., Michellon, R., Naudin, K., Razafintsalama, H., Rakotoarinivo, C., Rakotondramanana, T. and Seguy, L. (2008) Stylosanthes guianensis. Manual of Sowing Practice in Madagascar. Volume III. Antananarivo Madagascar. CIRAD. 12 p.

[19] Katunga, M.M.D. and Muhigwa, J.B. (2014) Assessing Post-Conflict Challenges and Opportunities of the Animal-Agriculture System in the Alpine Region of Uvira District in Sud-Kivu Province. DRC American Journal of Plant Sciences, 5, 2948-2955. https://doi.org/10.4236/ajps.2014.520311 http://www.scirp.org/journal/ajps

[20] Bruce, C., Pengelly, B., Brown, S., Donnelly, J., Eagles, D., Franco, A., Hanson, J., Mullen, B., Partridge, I., Peters, M. and Schultze-Kraft, R. (2005) Tropical Forages CSIRO Sustainable Ecosystems (CSIRO). Department of Primary Industries and Fisheries (DPI \& F Queensland), Centro Internacional de Agricultura Tropical (CIAT) and International Livestock Research Institute (ILRI). http://www.tropicalforages.info

[21] Barahenda, M., Shem, M.N., Kanuya, N.L., Ntakabeza, I., Gasana, J., Uwimana, G., Umunezero, O. and Uwumukiza, D. (2007) Yield Potential of Grass-Legume Pasture under Different Management Conditions. Research Journal of Animal Sciences, 1 , 59-61. 